\title{
Development of E-Learning in a Modern Technical University
}

\author{
Sergey Kulik ${ }^{1}$ Dr. Sc.; Ivan Aladyshkin ${ }^{2} \mathrm{PhD}$ \\ Svetlana Kalmykova ${ }^{3} \mathrm{PhD}$; (1) Maria Odinokaya ${ }^{4} \mathrm{PhD}$ \\ Peter the Great St. Petersburg Polytechnic University, Russia \\ kulik54@mail.ru'; i-bez@yandex.ru²; kalmykovas@mail.ru³; World.Maria@hotmail.com
}

\begin{abstract}
The article is devoted to the increasing role and prospects for the development of e-learning in modern transformation of higher polytechnic education. In the context of preventing the spread of coronavirus infection COVID-19 and the transition of universities to various forms of distance education, this issue is of particular relevance. The aim of the study is to assess the process of introducing e-learning into the educational process of higher technical educational institutions in Russia. The methodological basis of the work was the analytical and systematic approach to the study of the object of research using methods of data systematization, evaluative analysis and forecasting, as well as logical generalization. The authors come to the conclusion that the introduction of e-learning in technical universities in Russia until recently played a supporting role in the reorganization and optimization of the processes of training engineering personnel. The development of e-learning helped to reduce the costs of the educational process, reduce the number of employees, as well as solve the problem of the classroom fund. An important role in the development of e-learning was played by the desire to increase the rating indicators. The desire to expand non-budgetary sources of funding for modern technical universities and the possibility of implementing new learning models were only additional incentives for expanding the e-learning system. The results of this study can be used in further studying the digitalization of higher education and assessing the prospects for the development of professional training in Russia.
\end{abstract}

Keywords: e-learning, technical university, educational resources, distance learning.

\section{Introduction}

Today, the accelerating digital transformation of the higher professional education system is one of the key factors in the development of a higher technical school. One of the leading areas for the introduction of information and communication technologies into the education system is e-learning, the role of which is especially noticeable at the moment when all universities in the country continue to function remotely in the context of preventing the spread of coronavirus infection COVID-19. Under the circumstances, the preservation of the quality and high level of domestic polytechnic education directly depends on the level of development of the electronic information and educational environment and especially the e-learning system, as well as the digital literacy of employees (Osina, Tolstopyatenko, Malinovsky, 2021).

The relevance of this study is determined both by the current conditions of the functioning of a higher technical school, and by the need for its development, considering the socio-economic transformations of the last decades and the prospects of the 4th industrial revolution. The current conditions are determined not only by the fight against the escalation of coronavirus infection (Zenner, Oshkina, 2020; Arora, Srinivasan, 2020), but also by the forced intensification of research activities and optimization of the educational sphere, commercialization of the latter with the achievement of variability, accessibility and mobility of educational programs. The key prospects for the development of polytechnic education converge on the tasks of training personnel with competencies corresponding to the challenges of the digital economy, as well as rapid changes in socio-economic and industrial realities.

Many western and domestic authors carefully studied the problems of introducing e-learning into the higher education system. However, much less attention has been paid to the role of e-learning in the development of technical higher education. Moreover, most of the publications on this topic are devoted to either the implementation of online education in individual universities in the country (Nikiforov, 2019; Efremova, Rybakova, Alekseenko, 2015; Chupandina, Semenikhina, 2018), or applied and extremely specific nuances of the implementation of information and communication technologies in the functioning of a technical higher education (Queiros, Gomes, De Oliveira, 2017; Balogh, Koprda, 2012). In recent years, more and more researchers are asking questions about the role of e-learning in the development of higher technical education. The growing importance of training highly qualified technical specialists in 
a new economic situation requires an in-depth analysis of the e-learning system as one of the key factors in the development of technical universities in the country (Kozlov, Kankovskaya, Teslya, 2019).

The purpose of this study is to assess the process of introducing e-learning into the educational process of higher technical educational institutions in Russia to determine: the importance and role of online learning in the reorganization of the country's technical universities; the effectiveness of the Russian e-learning model in the field of professional training; the specifics of the relationship between the teaching staff and students of technical universities in the implementation of e-learning; the main directions for the introduction of new digital aspects of education and the selection among them of the most effective, and most importantly, meeting the planned development prospects of a higher technical school.

\section{Methodology}

A significant role in achieving the objectives of the study was played by SPbPU's internal regulatory documents and materials regulating the functioning of the electronic information and educational environment of the university. In the study and processing of the materials used in the article, the main ones were analytical and systematic approaches to the study of the research object using methods of data systematization, evaluative analysis and forecasting, as well as methods of pedagogical diagnostics. When formulating conclusions based on the research results, the method of logical generalization was used. The overall assessment of the results of the expansion of the e-learning system in technical universities took into account the experience gained by students and teachers using e-learning in an educational context. This experience was explored using an in-depth review and open-ended survey methods during the study.

To achieve the set research goals, we used the results of the conducted surveys in the form of a questionnaire among first-year students of SPbPU who are directly involved in e-learning initiatives. During the study, materials of a survey of the teaching staff were also involved, in which 120 teachers (10 from each SPbPU institute), 15 responsible for e-learning and distance learning technologies of the basic structural divisions of the university, heads of institutes and the SPbPU Center for Open Education took part.

\section{Results and Discussion}

Prospects for the development of polytechnic education are firmly associated with the new model of a technical university, which is so colourfully described by H. Etzkowitz, who considers the university to be the core of the knowledge society, the most important channel for technology transfer that plays a substantial role in the formation of a modern knowledge economy (Etzkowitz, 2008). The new technical university is considered a global, open, dynamically developing centre for the creation and commercialization of intellectual property, which not only fulfils orders for research and development, but actively creates technologies and technology companies (Kulik et al., 2020). This direction of transformation of the higher technical schools in Russia is also supported by the state.

Earlier, the idea of turning a university into a client-oriented organization that produces educational services was directly related to state policy in relation to higher professional education (changing the system of budget allocations, funding principles and system for evaluating the performance). The new model of a technical university, which occupies a leading position in the markets of high-tech sectors of the economy, is also a well-founded concept arising from government programs and initiatives (the Digital Economy national program and the earlier adopted National Technology Initiative).

The willingness to transform Russian technical universities is largely caused precisely by the accelerating digitalization of the economy, which directly affects projects for the modernization of higher professional education with the tasks of advanced restructuring and reorientation of specialist training. It should be noted that the qualitative changes in the reorganization of the country's leading technical universities in recent years have been directly related to the accelerated development of online education in the country's leading technical universities (Moscow Institute of Physics and Technology (MIPT), Moscow Institute of Engineering and Physics (MEPhI), Murmansk State Technical University (MSTU), Tomsk Polytechnic University (TPU), Peter the Great St. Petersburg Polytechnic University (SPbPU) and Ural Federal University (URFU)), and in other higher educational establishments (Higher School of Economics (HSE), Saint Petersburg State University (SPSU), Tomsk State University (TSU), Novosibirsk State University (NSU), Moscow State Institute of Music (MGIM), University of Information Technologies, Mechanics and Optics (ITMO), Moscow Institute of Steel and Alloys 
(MISiS)). A striking example is Peter the Great St. Petersburg Polytechnic University, where a sharp acceleration in the development of the e-learning system was recorded in 2016, when the university model 4.0 was updated, and this coincidence is not accidental and very indicative.

The introduction of e-learning turns out to be one of the key points in the overall inevitable digitalization of a modern university and the desire to intensify all levels of the scientific and educational process, as well as to increase the efficiency and effectiveness of the management of an educational institution as a whole (Vershitskaya et al., 2020). Under the current circumstances of the new industrial revolution, a large amount of data, the speed of response to requests dictate the need to use information systems at almost every stage of the university's functioning. At present, the opinion of those researchers who note that the problem of the development of the information and educational environment becomes the main one for the education system as a whole sound quite justified (Krevskiy, Bershadsky, Glotova, 2018). However, it should be recognized that the intensive introduction of e-learning in the new educational policy was conditioned by a number of other and much more vital circumstances. The administrations of higher educational institutions tried to reduce costs and optimize the educational process, primarily in non-core, but mandatory components. The expansion of the scope of digital technologies was expected to save time and material resources, reducing the staff to resolve or alleviate the problem of the audit fund while the number of applicants is increasing. Expectations were justified, although certainly to different degrees, which turned out to be an important moment in the restructuring of technical universities and increasing the profitability of education.

Optimization and reduction, as well as an increase in the profitability of education, refer to the inevitable expansion of off-budget sources of financing of a modern university. A technical university is no exception, but in the current reality it is necessary to effectively combine the progressive commercialization of higher professional education with a qualitative update of the content and technological aspects of future professional training that meet the expectations and demands of the market. In the context of a forced struggle to increase the competitiveness of domestic higher professional education and the rapid technical and technological renewal of the system of higher technical schools in the world, the time allotted for the restructuring of polytechnic education is significantly reduced.

It is assumed that the thoughtful introduction of e-learning will significantly accelerate both the commercialization of educational services and the updating of the content and technological aspects of training the specialists in demand. Moreover, commercially effective online education is the innovative activity of the university, which is not only directly related to modern technical and technological solutions, but also acts as an element of the digital economy. Technological novelty, economic effects, cross-sectoral nature and orientation to the global market, all of this can turn e-learning into a point of joining scientific, educational and entrepreneurial activities with the formation of an ecosystem of innovations in the life of a technical university. In the current situation, it is important for a university to turn e-learning into a source of financial income, not costs. Meanwhile, Russian universities have not yet succeeded in this and, accordingly, today, not so much commercial as administrative procedures for the development of e-learning are in force.

Currently, each educational institution creates its own information and educational environment. The amount of invested funds, the interest in its improvement and the development of e-learning largely determines the competitiveness of the university not only in the Russian but also in the international market of educational services (Nie et al., 2020). Therefore, the leaders of Russian online education quite naturally become the country's leading universities that have sufficient funds and technical capabilities to create an extensive e-learning system with the placement of online courses on leading Russian and international platforms, such as the National Platform for Open Education, Coursera, edX. Figure 1 shows the presence of Russian universities on the open educational platforms Coursera and edX.

It is difficult to overestimate the role of education in the information era, and the rapidly growing market for digital educational services turns out to be an important component of the new economic situation. In addition, in the context of measuring the knowledge economy (mass introduction of cyber-physical systems into production, automation of production processes, endowing devices with artificial intelligence and total digitalization), the digital format of education is acquiring special significance in the life of a modern university. With the development and spread of information and communication 
technologies, there has been a transformation of the human personality, according to the sociologists who study this problem (Rosenberg, Foshay, 2002).
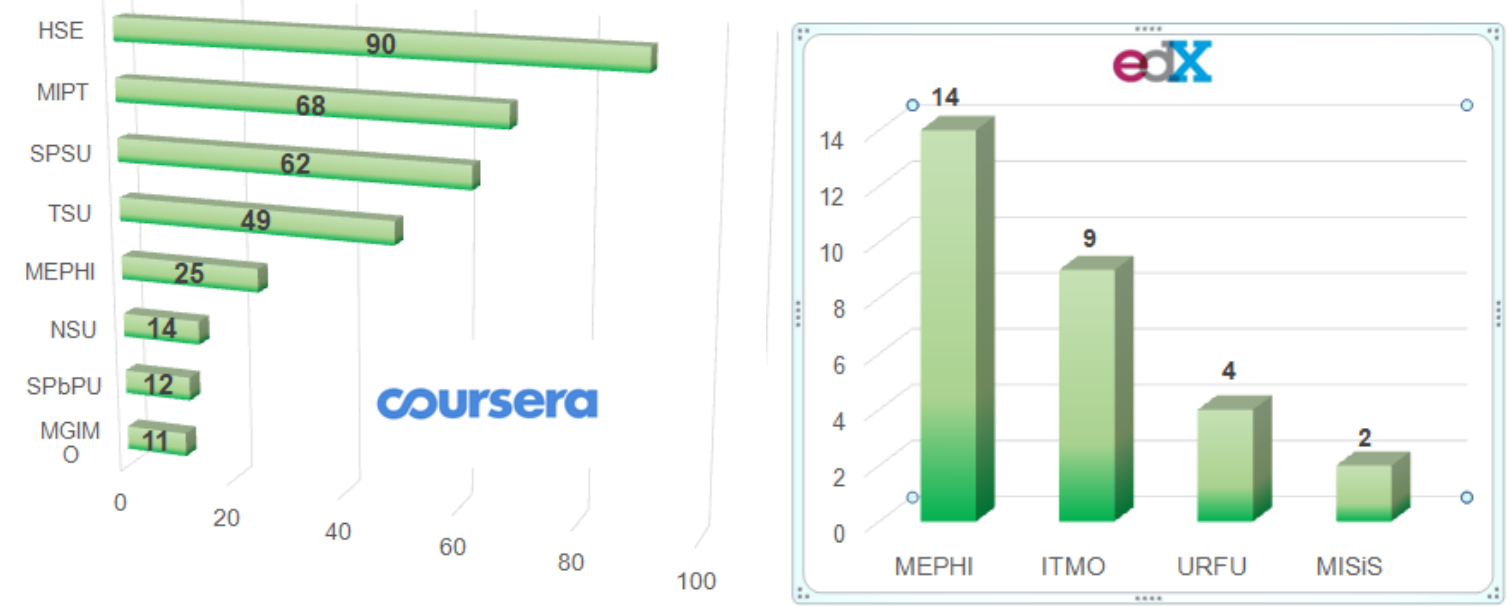

Figure 1. The presence of Russian universities on the open educational platforms Coursera and edX.

Indeed, a whole generation of people has grown up, for whom the mobile phone, computer and Internet are natural components of their living space, without which the functioning of any socio-economic system is unthinkable. Therefore, e-learning is as adequate as possible to the new digital format in key areas of the information society. In the future, the role of the digital component of educational services will only grow, and those universities that lag behind in the pace and quality of digitalization of education and commercialization of this sphere will find themselves in a very vulnerable position. The current situation is pushing Russian universities to activate the development of the e-learning system and increase the number of online courses, their students and qualified personnel involved in their development and administrative support. The pace of the development of Russian online education is clearly illustrated by the growth in the number of online courses on the National Open Education Platform, where in 2015 there were 51 courses, and in 2019 there were already 431 courses with almost 5 million listeners (Figure 2).

\section{Courses on the National Open Education} Platform

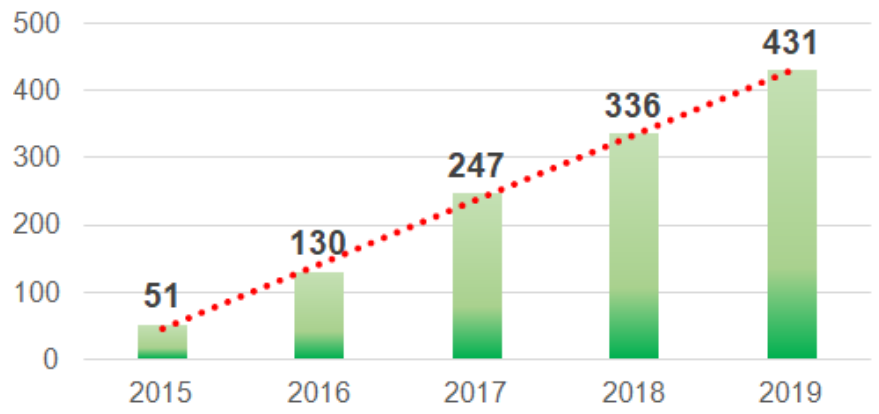

Figure 2. The pace of development of Russian online education.

The successful development of the e-learning system is possible if all basic components of the functioning and expansion of the e-learning system with competent personnel for its technical support and resource provision, a certain set of tools and technologies of information and educational space are available. At a minimum, it is necessary to have open education centres, educational portals, video conferencing, a number of electronic services (E-mail, file storage, virtual workstations) and various resources of the information and library complex (electronic catalogue, electronic library, databases). Developed e-learning system is an important indicator of the technological University, as connected with the use in the educational process of the latest achievements of information and telecommunication technologies in the design and improvement of e-learning. These conclusions are confirmed by the experience of introducing e-learning at Peter the Great St. Petersburg Polytechnic University. It is significant that the introduction and successful development of e-learning at SPbPU turned out to be closely related to the general digitalization of the university, which positions itself as a "digital university". The distributed e-learning system operates on the basis of the learning management systems 
Moodle, Sakai and Open edX, the Clipbucket video hosting platform, the ITMOproctor remote supervision system, and the WordPress content management system. Today, the distributed e-learning system at SPbPU is a network of educational portals and Massive Open Online Courses (MOOC) courses on various platforms, which makes it possible to implement the modular design of educational programs, individualize the learning path, academic mobility, and build network interaction.

SPbPU educational portals include a central server and portals to all key (17) structural units of the university, including portals for graduate school and state final certification. External portals for SPbPU courses are the Modern Digital Educational Environment of the Russian Federation (https://online.edu.ru/), the National Platform "Open Education" (https://openedu.ru/), Coursera (https://www.coursera.org/), Project Lectorium (https://www.lektorium.tv/). The distributed e-learning system functioning at SPbPU also includes a number of auxiliary systems: a video hosting server, a proctoring system, a web conference service, and an Examus online proctoring service. The development of the e-learning system is closely related to the creation of an extensive electronic information educational environment of the university (EIEE), which includes electronic information resources, electronic educational resources, a set of information technologies, telecommunication technologies, appropriate technological means and ensuring the development of educational programs by students in full independently from the location of the students. Key components of EIEE: Personal accounts of employees / students and portfolio; University websites; IT services; Information and library complex; Automated educational process control systems.

EIEE provides students with access to curricula, work programs of disciplines (modules), practice programs and final certification with publications of electronic library systems and electronic educational resources specified in work programs for all educational programs implemented at the university. In addition, EIEE SPbPU provides all types of classes, procedures for assessing learning outcomes, the implementation of which is provided with the use of e-learning distance learning technologies. Participants in the educational process have the opportunity to form an electronic portfolio of students, including the preservation of works, reviews and assessment of these works by any participant in the educational process. Interaction is created between the participants of the educational process, including synchronous and (or) asynchronous interaction, via the Internet. Today, there is a lot of talk and writing about the acceleration limit of scientific and technical transformations in the conditions of the $4^{\text {th }}$ industrial revolution and the need for a flexible system of polytechnic education that can quickly respond to changes in the socio-economic environment (Aladyshkin et al., 2020; Gabdrakhmanova, Izmailova, Vasilyeva, 2019). The traditional educational system, built on strict standards and unchanged during the implementation of a 4-or 6-year plan for training a specialist in the education strategy, does not have the time to master all innovations that occur in the advanced sectors of the modern economy, especially in conditions of technical uncertainty. Therefore, one of the main requirements for the higher professional education system today is its flexibility, changeability and openness (Gleason, 2018). Hopes are pinned on electronic forms of education for the possibility of implementing continuous, open education with a wide field of variability and interdisciplinary communication (Shipunova et al., 2018).

The obvious advantage of e-learning forms is their changeability, which is inherent in the universality of technological processes for creating, storing and using educational information resources (Katane, Katans, Vavere, 2012). The combination of information and communication technologies in modern universities is moving to a new quality of communication between students and educational institutions, when the "classic" e-learning is gradually replaced by smart education, characterized by adaptation to the user's needs during training. They are being modernized as information technology develops, which makes it possible to design an e-learning system, adjusting it in accordance with the current and future demands of the educational services market or changing the training format. The latter is well illustrated by the current situation, when, in the context of preventing the spread of coronavirus infection, almost all Russian universities have switched to partial or full distance learning. It is the distributed e-learning system created at SPbPU in recent years that has made it possible to forcefully transfer the educational process to a distance format.

It is believed that the developed e-learning system significantly facilitates the integration of the university and its individual programs directions into the international scientific community. The goal of creating a mobile, extensive system of additional training, retraining, and advanced training, which is not limited to the resources of the university, but is associated with the global scientific and educational community, with prestigious universities and world-renowned scientists, is quite achievable. 
It is also important that the e-learning system is much easier to adjust. Existing educational programs and individual disciplines are supplemented, and they include separate blocks or competencies. As a result, the list of students' knowledge and skills becomes adjustable to meet changing socioeconomic needs and challenges (Meskhi, Ponomareva, Ugnich, 2019; Gilmanshin, Gilmanshina, 2018).

Moreover, the variability of the educational process achieved through the e-learning system allows students to choose an educational trajectory, plan the time, place and duration of classes (Krasnov et al., 2018) If we turn to the experience of SPbPU, the university implements the so-called "Mobility Module" - an educational cycle within the educational program, which represents an additional educational trajectory for students beyond training in the main educational direction. The mobility module refers to the variable part of educational programs and is implemented as a choice of a number of disciplines by students. The curriculum mobility module is implemented in two optional disciplines:

1. "Educational Foresight", which includes two blocks: a mandatory block for all (1 credit unit) and a variable block (duration varies), containing a list of online courses offered for the study;

2. "Career adaptability", which makes it possible to credit learning outcomes obtained in the framework of academic mobility and/or in other organizations.

Independence in the choice of educational paths develops the skills of future specialists to search for information, the most effective solutions within their own training, the use of various sources of information to solve emerging problems, i.e., the skills that are so necessary in the new economic realities. Thus, the e-learning system significantly simplifies and accelerates the process of expanding the range of competencies of the student with the intensification of continuous self-development in a dynamically changing world. A modern technical university is also faced with the task of developing an educational model that makes it possible to accompany a person throughout the life through a flexible system of modules, courses, and programs at the request of the student and the challenges of the market.

The results of the survey conducted in the form of a questionnaire among SPbPU students and teachers who are directly involved in e-learning initiatives speak volumes about the positive perception of the increased variability of the educational process and the students' independent choice of the educational trajectory. Negative responses and problems noted by the respondents turned out to be associated with particular moments: the level of computer literacy, the level of technical support and university support.

The use of information and educational resources with access to them from any point of the network and their transfer to other addresses determines the maximum availability and mobility of e-learning, regardless of the geographical and temporary location of the student and educational institutions, researchers and scientific institutions. The weakening of barriers of space (distance, territory, borders) and time (time zones and work schedules) expands the boundaries of educational services of the university with access to many sources of scientific and educational information (electronic libraries, databanks, knowledge bases, scientific publications, etc.). The developed e-learning system allows to significantly reduce the costs that traditional classroom practice requires, providing living and learning conditions for foreign students, as well as attracting outstanding foreign specialists. It is no coincidence that the image of a virtual university is on the agenda, in which at least, a significant proportion of educational and scientific processes occur in virtual parameters (Dneprovskaya et al., 2018).

The development of EIEE at SPbPU sets new guidelines for thinking in the development of the educational process, ensuring not only intra-university needs, but the fulfillment of external orders and attracting outside students and listeners. Therefore, in the context of the prevention of coronavirus infection in the spring and summer of 2020, more than 40,000 people were recorded at SPbPU courses hosted only on the National Platform "Open Education" at the request of other universities. The teaching staff of the university is also actively involved in the development of courses, and the parameters of motivation include both the possibility of implementing a wide range of disciplines, advanced training and professional retraining programs, and the growth of the intra-university rating depending on the number of developed online courses, as well as percentage of the cost of network agreements concluded with partner universities / issued certificates.

If we return to the issue of optimizing the educational process in technical universities, it should be pointed out that it is often associated with both cost savings and the approval of strict priorities in the training of future specialists with a noticeable reduction in costs for non-core disciplines. Optimization of the educational process also implies the necessary reduction of the academic "load" of the teaching 
staff for the state-forced intensification of research work of universities. Electronic forms of training were initially intended to improve the effectiveness of the teacher. Proponents of e-learning appeal to reducing the time spent searching, transmitting and working with educational materials, simplifying the processing of considerable amounts of data, and auto-mating many routine processes (checking tasks, student progress). As a result of freeing up the time of university employees, it becomes possible to transfer the load from educational practice to research work, activate publication activity and develop innovative training technologies. It cannot be said that today, as a result of the introduction of e-learning for the bulk of the teaching staff, there has really been a qualitative redistribution of the workload and the release of time for research work. This task remains rather for the future. Meanwhile, based on the example of $\mathrm{SPbPU}$, we can conclude that there is an inevitable redistribution of functions among the teaching staff to those who accompany, support and actively participate in the expansion of the distributed e-learning system and those who implement the main pedagogical process or research activity.

There are different attitudes to e-learning and the openness of the educational process, and the Russian scientific community remains extremely ambivalent about distance learning technologies, especially in the bulk of the teaching staff of universities (Almazova et al., 2020). However, all world's universities are expanding their MOOC programs. Tens of millions of young people are studying online courses, and their number is only growing. The numbers speak volumes about the growing demand for e-learning. Figures 3, 4, 5 show five-year trends - from 2014 to 2018 and an increase in the number of users, courses and listeners on open educational platforms.

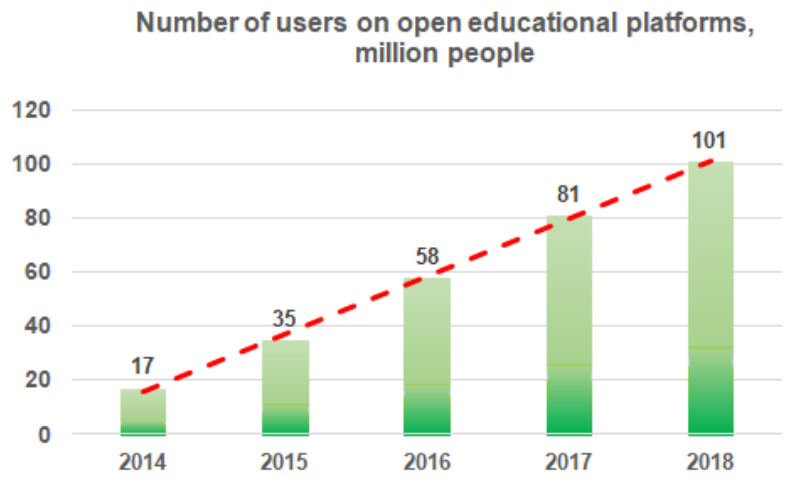

Figure 3. Dynamics of the number of users on open educational platforms.

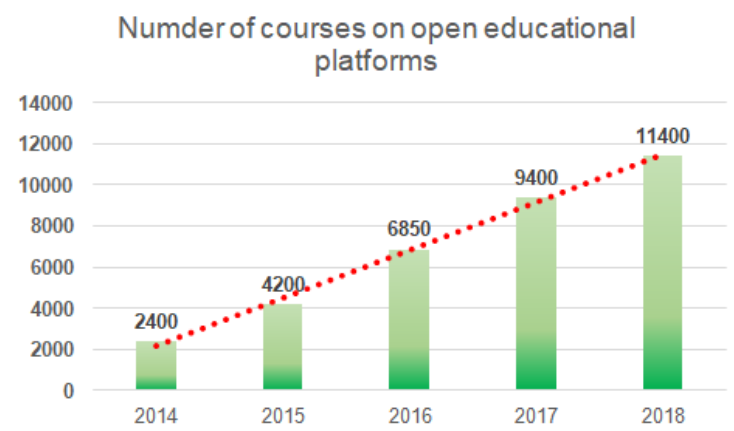

Figure 4. Dynamics of the number of courses on open educational platforms.

And after all, these are the numbers before those conditions for preventing the spread of the coronavirus infection COVID-19, which led to an unprecedented demand for online education. Perhaps, due to emergency circumstances and full-scale testing of the distance learning format for most educational institutions in developed countries, 2020 will be a turning point in the development of e-learning. Some of the effectiveness of online courses is as obvious as their profitability and commercialization opportunities. Ultimately, the introduction of e-learning is one of the measures to improve the scientific and educational reputation of Russian polytechnic education. 


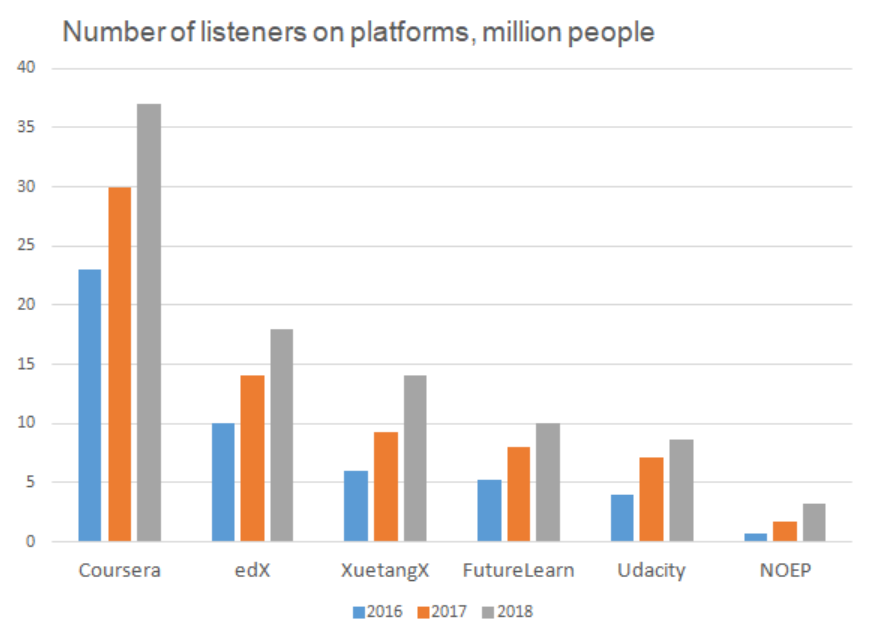

Figure 5. Dynamics of the number of listeners on platforms.

Thoughtful digitalization of polytechnic education with systematic and effective use of e-learning opportunities contributes to the necessary transformation of the national higher engineering school. At the moment, it is important for the University community to understand the direct relationship between the development of e-learning and the advanced renovation of the higher school of engineering, to transform Russian technical universities into global, open, dynamically developing centres for the creation and commercialization of intellectual property, occupying leading positions in the markets of high-tech industries.

And here it is necessary to clearly define the direction of the development of the e-learning system in the context of increasing the competitiveness of Russian technical universities, the formation of new models of their functioning with a variable and effective system of training engineering personnel adequate to the digital age:

- accumulation and implementation of world experience achievements in the further development of the considered sphere of educational technologies;

- focus on the future: understanding trends in future changes in e-learning, implementing and improving its smart components;

- progressive renovation of technical and technological components in the design and improvement of e-learning;

- innovative updating of forms and methods of training with the development of variability and adaptability of curricula and training formats in the light of changing socio-economic needs;

- qualitative deepening of the integration of electronic educational programs of Russian technical universities into the global e-learning system and the development of inter-national partnerships in this field;

- increase the profitability and commercial efficiency of online training;

- general development of the electronic information and educational environment of Russian universities.

\section{Conclusions}

At the moment, it is quite justified to say that the availability and successful development of the e-learning system is one of the most important conditions for the functioning of a modern competitive technical university. And it should be recognized that online education and the electronic information and educational environment of the institution in general are well-established not only in the list of integral components of a modern higher technical school, they are increasingly associated with the future of polytechnic education.

The main conclusion of the study is that, until recently, the introduction of e-learning in technical universities in Russia played a supporting role in the reorganization and optimization of the processes of training engineering personnel. The development of e-learning helped to reduce costs and optimize the educational process, primarily in non-core, but mandatory components, as a result, and a reduction 
in the number of employees and, if not resolution, then mitigate the problem of the classroom fund against the background of an increase in the number of applicants. An important role in the development of the e-learning system was played by the fact that its development turned out to be an important component in the rating indicators. Therefore, the accelerated timing of the introduction of e-learning (as some researchers write) was not dictated by the prospects of the 4th industrial revolution and the accelerated digitalization of the economy, but by the tasks of reorganizing and optimizing the educational process.

The desire to increase the profitability of education and expand non-budgetary sources of funding for a modern technical university were only additional incentives for expanding the e-learning system. Moreover, it was not possible to achieve commercial efficiency, the formation of stable income streams and less dependence on budget financing.

However, today, other promising areas for the further implementation and development of online learning are quite clearly emerging: 1) training of new specialists that meet market expectations; 2) the formation of information conditions for the creation of advanced technologies and technology companies (in cooperation with the business community, industrial leaders - Russian and global); 3) the possibility of implementing modular construction of educational programs, as well as individualizing the learning path; 4) increasing the competitiveness of the university in the rapidly growing digital market of educational services.

When evaluating the e-education system, it is always important to keep in mind that it is based on those information and communication technologies that are crucial or, as they are often called, critical technologies. The latter imply an intersectoral nature, create significant prerequisites for the development of many technological areas or areas of research and development, and together make a major contribution to solving key problems of development and progress. Today, there is every reason to agree with the opinion that the role of critical technologies in education is related to those forms of education that are built on the means of information and computing and telecommunications technologies, i.e., with the electronic format of education.

The results of this study can be used in further studying the digitalization of higher education and assessing the prospects for the development of professional training in Russia.

\section{Bibliography}

1. Aladyshkin I.A., Kulik S.V., Odinokaya M.A., Safonova A.S., Kalmykova S.V. (2020). Development of Electronic Information and Educational Environment of the University 4.0 and Prospects of Integration of Engineering Education and Humanities. In Z. Anikina (Ed.), Integrating Engineering Education and Humanities for Global Intercultural Perspectives. IEEHGIP 2020. Lecture Notes in Networks and Systems, 131. Cham: Springer, 659-671. doi: 10.1007/978-3-030-47415-7_70

2. Almazova N., Krylova E., Rubtsova A., Odinokaya M. (2020). Challenges and Opportunities for Russian Higher Education amid COVID-19: Teachers' Perspective Education Science, 10(12), 368 doi: 10.3390/educsci10120368

3. Arora A.K., Srinivasan R. (2020). Impact of Pandemic COVID-19 on the Teaching-Learning Process: A Study of Higher Education Teachers. Prabandhan: Indian Journal of Management 13(4), 43-56. doi: 10.17010/pijom/2020/v13i4/151825

4. Balogh Z., Koprda S. (2012). Modeling of Control in Educational Process by LMS. In M. Capay, M. Mesarosova, V. Palmarova (Eds.), The Proceedings of the International Scientific Conference Distance Learning in Applied Informatics, 9. Sturovo, Slovakia, 43-51.

5. Chupandina E.E., Semenikhina A.V. (2018). Vnedreniye onlayn-obucheniya v Voronezhskom gosudarstvennom universitete [Implementation of online learning at Voronezh State University]. Vysshee obrazovanie $v$ Rossii, 8-9, 103-110. doi: 10.31992/0869-3617-2018-27-8-9-103-110 (in Russian, abstract in English)

6. Dneprovskaya N.V., Bayaskalanova T.A., Ruposov V.L., Shevtsova I.V. (2018). Study of Digitization of Russian Higher Education as Basis for Smart Education. IEEE International Conference Quality Management, Transport and Information Security, Information Technologies (IT\&QM\&IS), 607-611. doi: 10.1109/ITMQIS.2018.8524945

7. Efremova E.P., Rybakova E.V., Alekseenko I.V. (2015). O nekotorykh vozmozhnostyakh realizatsii elektronnogo obucheniya $\mathrm{v}$ obrazovatel'noy srede tekhnicheskogo vuza [On some possibilities of implementing e-learning in the educational environment of a technical university]. 
Vestnik TGPU, 12, 77-80. Retrieved from https://vestnik.tspu.edu.ru/files/vestnik/PDF/articles/efrem ova_e._p._77_80_12_165_2015.pdf (in Russian)

8. Etzkowitz H. (2008). The triple helix: University-Industry-Government Innovation in Action. New York: Routledge. doi: 10.4324/9780203929605

9. Gabdrakhmanova K.F., Izmailova G.R., Vasilyeva E.R. (2019). E-learning Environment as a Means for a Modern Engineer Training. In D.B. Solovev (Ed.), The Proceedings of the International Scientific Conference Advances in Economics, Business and Management Research, Far East Con (ISCFEC 2018), 47. Atlantis Press, 244-247 doi: 10.2991/iscfec-18.2019.60

10. Gilmanshin I.R., Gilmanshina S.I. (2018). Technology of e-learning in the university education. In IOP Conference Series: Materials Science and Engineering, 412, 012022 doi: 10.1088/1757$899 X / 412 / 1 / 012022$

11. Gleason N.W. (2018). Higher Education in the Era of the Fourth Industrial Revolution. Singapore: Palgrave Macmillan. doi: 10.1007/978-981-13-0194-0

12. Katane I., Katans E., Vavere G. (2012). Environment of distance learning for humanization and democratization of education: the historical aspect. In V. Dislere (Ed.), The Proceedings of the International Scientific Conference Rural Environment. Education. Personality (REEP), 5. Jelgava: LLU, 35-42. Retrieved from https://lufb.llu.lv/conference/REEP/2012/REEP-2012-proceedings-E-ISSN-2255-808X.pdf\#page=36

13. Kozlov A., Kankovskaya A., Teslya A. (2019). The investigation of the problems of the digital competences formation for Industry 4.0 workforce. In IOP Conference Series: Materials Science and Engineering, 497, 012011. doi: 10.1088/1757-899X/497/1/012011

14. Krasnov S.V., Kalmykova S.V., Abushova E.A., Krasnov A.S. (2018). Problems of Quality of Education in the Implementation of Online Courses in the Educational Process International Conference on High Technology for Sustainable Development (HiTech) IEEE doi: 10.1109/HiTech.2018.8566618

15. Krevskiy I.G., Bershadsky A., Glotova T. (2018). Research Competence for Development of Distance Education in Russian Universities. In V. Mkrttchian, L. Belyanina (Eds.), Handbook of Research on Students' Research Competence in Modern Educational Contexts. IGI Global, 385-408. doi: 10.4018/9781-5225-3485-3.ch020

16. Kulik S., Aladyshkin I., Odinokaya M., Kulikova E. (2020). Formation of the Electronic Informational and Educational Environment in the Prospects of the University 4.0. In V. Dislere (Ed.), The Proceedings of the International Scientific Conference Rural Environment. Education. Personality (REEP), 13. Jelgava: Latvia University of Life Sciences and Technologies, 294-302. doi: 10.22616/REEP.2020.035

17. Meskhi B., Ponomareva S., Ugnich E. (2019). E-learning in higher inclusive education: needs, opportunities and limitations. International Journal of Educational Management, 33(3), 424-437. doi: 10.1108/IJEM-09-2018-0282

18. Nie D., Panfilova E., Samusenkov V., Mikhaylov A. (2020). E-Learning Financing Models in Russia for Sustainable Development. Sustainability, 12(11), 4412. doi: 10.3390/su12114412

19. Nikiforov I.I. (2019). Information activity of the future engineer in the digital educational environment. Educational Bulletin Consciousness, 21(10), 35-40. doi: 10.26787/nydha-2686-6846-2019-21-10-35-40 (in Russian, abstract in English)

20. Osina D.M., Tolstopyatenko G.P., Malinovsky A.A. (2021). Digitalization of Higher Legal Education in Russia in the Age of Covid-19. In S. Ashmarina, V. Mantulenko, M. Vochozka (Eds.), Engineering Economics: Decisions and Solutions from Eurasian Perspective. Engineering Economics Week 2020. Lecture Notes in Networks and Systems, 139. Cham: Springer, 392-398. doi: 10.1007/978-3-030-53277-2_47

21. Queiros L.M., Gomes A.S., De Oliveira F.K. (2017). Learning Experiences Design: Integration of eLearning Environments. In the Iberian Conference on Information Systems and Technologies (CISTI), 12, 1-4. Lisbon, Portugal. doi: 10.23919/CISTI.2017.7975938

22. Rosenberg M., Foshay R. (2002). E-learning: Strategies for delivering knowledge in the digital age. Performance Improvement 41(5), 50-51. doi: 10.1002/pfi.4140410512

23. Shipunova O.D., Berezovskaya I.P., Mureyko L.M., Evseev V.V., Evseeva L.I. (2018). Personal intellectual potential in the e-culture conditions. Education, 39(40), 15-19. Retrieved from http://www.revistaespacios.com/a18v39n40/a18v39n40p15.pdf

24. Vershitskaya E.R., Mikhaylova A.V., Gilmanshina S.I., Dorozhkin E.M., Epaneshnikov V.V. (2020). Present-day management of universities in Russia: Prospects and challenges of e-learning. Educational and Information Technologies, 25, 611-621. doi: 10.1007/s10639-019-09978-0

25. Zenner T.S., Oshkina A.V. (2020). Osobennosti obucheniya v onlayn-formate v vysshey shkole $\mathrm{v}$ forsirovannykh usloviyakh. International Journal of Humanities and Natural Sciences 5-3(44), 170-177. doi: 10.24411/2500-1000-2020-10576 (in Russian, abstract in English) 